\title{
Sandwich-Type Lanthanide(III) Dinaphthalocyanine Complexes Possessing an Intensive Absorption in the Near IR Region: Synthesis and Investigation of Properties
}

\author{
Tatiana V. Dubinina, ${ }^{\mathrm{a}, \mathrm{b}}$ @ Viktor E. Pushkarev, ${ }^{\mathrm{a}, \mathrm{b}}$ Stanislav A. Trashin, ${ }^{\mathrm{b}}$ \\ Kseniya V. Paramonova, ${ }^{a}$ and Larisa G. Tomilova ${ }^{a, b}$
}

Dedicated to Academician Aslan. Yu. Tsivadze on the occasion of his Anniversary

\author{
a Department of Chemistry, M.V. Lomonosov Moscow State University, 119991 Moscow, Russian Federation \\ ${ }^{\mathrm{b}}$ Institute of Physiologically Active Compounds, Russian Academy of Sciences, 142432 Chernogolovka, Moscow Region, \\ Russian Federation \\ @Corresponding author E-mail: dubinina.t.vid@gmail.com
}

\begin{abstract}
Phenoxysubstituted sandwich-type naphthalocyanine complexes of lanthanides were synthesized in a melt under the heating and using microwave irradiation assisted approach. The intensive absorption in the near IR region up to 2000 $n m$ was found. All complexes obtained were characterized using MALDI-TOF mass spectrometry, UV/Vis/NIR and ${ }^{1} H$ NMR spectroscopy. The presence of reversible redox properties was demonstrated by cyclic voltammetry for a wide range of potentials $(-1.6 \div 1.6 \mathrm{~V})$.
\end{abstract}

Keywords: Dinaphthalocyanine, lanthanide, near IR region, electrochemistry, microwave irradiation.

\section{Аинафталоцианиновые комплексы лантанидов(III) сэндвичевого строения, обладающие интенсивным поглощением в ближнем ИК Аиапазоне: синтез и исследование свойств}

\author{
Т. В. Аубинина, ${ }^{a, b @ ~ B . ~ Е . ~ П у ш к а р е в, ~}{ }^{a, b}$ C. А. Трашин, ${ }^{b}$ \\ K. В. Парамонова, ${ }^{a} \Lambda$. Г. Томилова ${ }^{a, b}$
}

Посвящается акаgемику Аслану Юсуповичу Циваgзе по случаю его 70-летнего юбилея

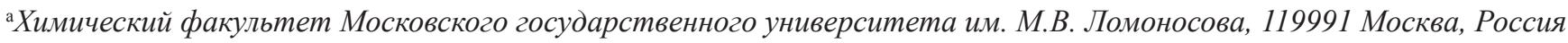
${ }^{\mathrm{b}}$ Институт физиологически активных веществ РАН, 142432 Черноголовка, Россия

${ }^{\circledR}$ E-mail: dubinina.t.vid@gmail.com
}

\begin{abstract}
Синтезированы феноксизамещченные динафталочианиновые комплексы РЗЭ. Обнаружено интенсивное поглощеение данных соединений в ближней ИК области вплоть до 2000 нм. Установлены корреляции между радиусами ионов РЗЭ и значениями редокс потенциалов.
\end{abstract}

Ключевые слова: Динафталоцианин, лантанид, ближняя ИК область, электрохимия, микроволновое излучение. 


\section{Introduction}

Phthalocyanines with an extended $\pi$-conjugation system are of increasing importance due to the presence of absorption in the near-IR region. ${ }^{[1-4]}$ It is known that the widening of the conjugation system causes a considerable (up to $100 \mathrm{~nm}$ ) bathochromic shift of the $Q$-band in the electronic absorption spectra of naphthalocyanines in comparison with the spectra of phthalocyanines..$^{[5-8]}$ An introduction of functional groups into naphthalocyanine ligands, a possibility of a central ion incorporation into the macrocycle, and an ability, similarly to phthalocyanines, to form double decker complexes allows one to vary their properties within a wide range. ${ }^{[9]}$ So a direct synthesis of new substituted naphthalocyanines is an important problem, as well as a study of their properties in order to establish the structure-properties relationship and to broaden the scope of their application. The main purpose of present work was the synthesis of phenoxysubstituted dinaphthalocyanine complexes of lanthanides and determination of correlations between their spectral and electrochemical properties and values of radius of central ion.

\section{Experimental}

Column chromatography was carried out on neutral MNAluminiumoxid. The electrolyte $\left[\mathrm{Bu}_{4} \mathrm{~N}^{+}\left[\mathrm{BF}_{4}\right]^{-}\right.$(Sigma-Aldrich) was recrystallized twice from ethyl acetate/hexane $(9: 1, \mathrm{~V} / \mathrm{V})$ and dried under vacuum at $70{ }^{\circ} \mathrm{C}$. All other reagents and solvents were obtained or distilled according to standard procedures. The salts $\mathrm{Ln}(\mathrm{OAc})_{3} \cdot \mathrm{nH}_{2} \mathrm{O}$ were dried immediately before use in a vacuum desiccator for $4 \mathrm{~h}$ at $70^{\circ} \mathrm{C}$. 6,7-Diphenoxynaphthalene-2,3dicarbonitrile 1 was obtained by the earlier published procedure. ${ }^{[10]}$

Electronic absorption (UV-vis) spectra were recorded on a ThermoSpectronic Helios- $\alpha$ spectrophotometer using quartz cells $(0.5 \times 1 \mathrm{~cm}) . \mathrm{UV} / \mathrm{Vis} / \mathrm{NIR}$ measurements were made with a Hitachi $\mathrm{U}-4100$ spectrophotometer in quartz cells $(1 \times 1 \mathrm{~cm})$ using $\mathrm{CCl}_{4}$ as a solvent. MALDI-TOF mass spectra were taken on a VISION-2000 mass spectrometerwith $\alpha$-cyano-4-hydroxycinnamic acid(CHCA) as the matrix. ${ }^{1} \mathrm{H}$ NMR spectra of reduced forms of dinaphthalocyanine complexes, which were generated by the addition of $\mathrm{N}_{2} \mathrm{H}_{4} \cdot \mathrm{H}_{2} \mathrm{O}(1-2$ vol.\%), were recorded on a Bruker AVANCE 400 spectrometer $(400.13 \mathrm{MHz})$ at $20{ }^{\circ} \mathrm{C}$ (if not additionally specified). Chemical shifts are given in ppm relative to $\mathrm{SiMe}_{4}$.

Cyclic voltammetry was performed with IPC-Pro (Econix, Moscow, Russia) electrochemical interface using a conventional three-electrode cell with a Pt-disk $(2.0 \mathrm{~mm}$ in diameter) working and Pt-foil counter electrodes. The calomel reference electrode (SCE, $3.5 \mathrm{M} \mathrm{KCl}$ ) was connected to the solution through a salt bridge and a Luggin capillary, the tip of which was placed close to the working electrode. The junction potential of the reference electrode was corrected to a ferrocenium ${ }^{+} /$ferrocene $\left(\mathrm{Fc}^{+} / \mathrm{Fc}\right)$ couple. $o$-Dichlorobenzene (o-DCB, $99 \%$ Sigma-Aldrich, HPLCgrade) freshly passed through an $\mathrm{Al}_{2} \mathrm{O}_{3}$ was used as a solvent. Blank voltammograms were recorded in the solution of $0.15 \mathrm{~mol} / 1$ $\mathrm{Bu}_{4} \mathrm{NBF}_{4}\left(\right.$ Sigma-Aldrich, dried under vacuum at $+80{ }^{\circ} \mathrm{C}$ ) before $0.2-1 \mathrm{mmol} / 1$ of sample was introduced. All solutions were bubbled with argon for $20 \mathrm{~min}$ before measurements were taken.

Synthesis of lanthanide bis[(3,4,12,13,21,22,30,31octaphenoxy)-2,3-naphthalocyanines] (2-4) in a melt of compound 1 (general procedure). The mixture of 6,7-diphenoxynaphthalene2,3-dicarbonitrile $1(0.3 \mathrm{~g}, 0.83 \mathrm{mmol})$ and $\mathrm{Ln}(\mathrm{OAc})_{3} \cdot n \mathrm{H}_{2} \mathrm{O}(0.17$ $\mathrm{mmol})(\mathrm{Ln}=\mathrm{Lu}, \mathrm{Er}, \mathrm{Eu})$ was heated with gradual increasing of temperature from 220 to $310{ }^{\circ} \mathrm{C}$. The reaction mixture was kept at this temperature for $2 \mathrm{~h}$ until the reaction mass solidified.
Then, the reaction mixture was dissolved in DMF and target dinaphthalocyanine was precipitated with methanol. The precipitate was filtered off and dried at $70^{\circ} \mathrm{C}$, dissolved in benzene, and purified by column chromatography $\left(\mathrm{THF}-\mathrm{C}_{6} \mathrm{H}_{6}(1: 10), \mathrm{Al}_{2} \mathrm{O}_{3}\right)$.

Lutetium bis $[(3,4,12,13,21,22,30,31$-octaphenoxy)-2,3-naphthalocyanine] (2). The yield was $130 \mathrm{mg}$ (41\%). UV-vis (THF) $\lambda_{\max } \mathrm{nm}$ (lge): 339 (5.38), 590 (4.74), 677 (4.78), 758 (5.24). MS (MALDI-TOF), $m / z: 3073[\mathrm{M}]^{+}, 2980[\mathrm{M}-\mathrm{OPh}]^{+}, 2888[\mathrm{M}-2 \mathrm{OPh}]^{+}$, $2796[\mathrm{M}-3 \mathrm{OPh}]^{+}, 2703[\mathrm{M}-4 \mathrm{OPh}]^{+} .{ }^{1} \mathrm{H}$ NMR $\left(\mathrm{THF}-d_{8}+\mathrm{N}_{2} \mathrm{H}_{4} \cdot \mathrm{H}_{2} \mathrm{O}\right.$ (1-2 vol.\%), $298 \mathrm{~K}) \delta_{\mathrm{H}}$ ppm: 7.21 (t, $\left.16 \mathrm{H}, p-\mathrm{H}_{\mathrm{Oph}}, J=7.1 \mathrm{~Hz}\right) ; 7.29$ $\left(\mathrm{d}, 32 \mathrm{H}, o-\mathrm{H}_{\mathrm{OPh}}, J=7.7 \mathrm{~Hz}\right) ; 7.50$ (t, $\left.32 \mathrm{H}, m-\mathrm{H}_{\mathrm{OPh}}, J=7.2 \mathrm{~Hz}\right) ; 8.04$ $\left(\mathrm{s}, 16 \mathrm{H}, \beta-\mathrm{H}_{\mathrm{Ar}}\right) ; 9.07\left(\mathrm{~s}, 16 \mathrm{H}, \alpha-\mathrm{H}_{\mathrm{Ar}}\right)$.

Erbium bis $[(3,4,12,13,21,22,30,31$-octaphenoxy)-2,3-naphthalocyanine] (3). The yield was $150 \mathrm{mg}$ (47\%). UV-vis (THF) $\lambda_{\max } \mathrm{nm}(\lg \varepsilon): 336$ (5.42), 591 (4.77), 679 (4.87), 762 (5.33). MS (MALDI-TOF), $m / z: 3065[\mathrm{M}]^{+}, 2973[\mathrm{M}-\mathrm{OPh}]^{+}, 2881[\mathrm{M}-2 \mathrm{OPh}]^{+}$. ${ }^{1} \mathrm{H}$ NMR (THF- $\left.d_{8}+\mathrm{N}_{2} \mathrm{H}_{4} \cdot \mathrm{H}_{2} \mathrm{O}(1-2 \mathrm{vol} . \%), 298 \mathrm{~K}\right) \delta_{\mathrm{H}}$ ppm: $9.95-$ $12.04\left(\mathrm{~m}, 40 \mathrm{H}, \mathrm{H}_{\mathrm{OPh}}\right) ; 19.87\left(\mathrm{~s}, 16 \mathrm{H}, \beta-\mathrm{H}_{\mathrm{Ar}}\right) ; 36.72\left(\mathrm{~s}, 16 \mathrm{H}, \alpha-\mathrm{H}_{\mathrm{Ar}}\right)$. Europium bis $[(3,4,12,13,21,22,30,31$-octaphenoxy)-2,3naphthalocyanine] (4). The yield was $174 \mathrm{mg}$ (55 \%). UV-vis (THF) $\lambda_{\max } \mathrm{nm}(\lg \varepsilon): 339,594,623,682,769 . \mathrm{MS}$ (MALDI-TOF), $m / z: 3050[\mathrm{M}]^{+}, 2958[\mathrm{M}-\mathrm{OPh}]^{+} .{ }^{1} \mathrm{H}$ NMR $\left(\mathrm{THF}-d_{8}+\mathrm{N}_{2} \mathrm{H}_{4} \cdot \mathrm{H}_{2} \mathrm{O}\right.$ $(1-2$ vol.\%), $298 \mathrm{~K}) \delta_{\mathrm{H}} \mathrm{ppm}: 7.07-7.70\left(\mathrm{~m}, 40 \mathrm{H}, \mathrm{H}_{\mathrm{OP}}\right) ; 8.96(\mathrm{~s}, 16 \mathrm{H}$, $\left.\beta-\mathrm{H}_{\mathrm{Ar}}\right) ; 11.06\left(\mathrm{~s}, 16 \mathrm{H}, \alpha-\mathrm{H}_{\mathrm{Ar}}\right)$.

Synthesis of lanthanide bis[ $[3,4,12,13,21,22,30,31$ octaphenoxy)-2,3-naphthalocyanines] (3, 4) using microwave irradiation (general procedure). The mixture of compound $1(0.3$ $\mathrm{g}, 0.83 \mathrm{mmol})$ and $\mathrm{Ln}(\mathrm{OAc})_{3} \cdot n \mathrm{H}_{2} \mathrm{O}(0.17 \mathrm{mmol})(\mathrm{Ln}=\mathrm{Er}, \mathrm{Eu})$ was placed into a microwave oven with the power of irradiation of $700 \mathrm{~W}$. The reaction time was 5-7 min. Then, the reaction mixture was dissolved in DMF, and dinaphthalocyanine was precipitated with methanol. The precipitate was filtered off and dried at $70{ }^{\circ} \mathrm{C}$, dissolved in benzene, and purified by column chromatography (THF- $\mathrm{C}_{6} \mathrm{H}_{6}(1: 10), \mathrm{Al}_{2} \mathrm{O}_{3}$ ). The yields of compounds $\mathbf{3}$ and $\mathbf{4}$ were $105 \mathrm{mg}(33 \%)$ and $123 \mathrm{mg}$ (39\%), respectively. The characteristics were identical with those obtained by the first method.

\section{Results and Discussion}

\section{Synthesis}

Starting dinitrile 1 was obtained by the earlier published procedure ${ }^{[10]}$ Dinaphthalocyanine complexes 2-4 were synthesized by the melting of naphthalodinitrile $\mathbf{1}$ and corresponding salts of lanthanide (Scheme 1).

This method considerably differs from the synthesis in solution ${ }^{[11-13]}$ since the starting nitrile serves simultaneously as the reagent and the reaction medium. According to this method, the synthesis of dinaphthalocyanines 2-4 was performed by melting of a mixture of dinitrile 1 with the corresponding lanthanide acetates by the gradual increase of temperature from 220 to $310{ }^{\circ} \mathrm{C}$ and by keeping at this temperature until the reaction mixture was solidified $(\sim 2$ h). Compounds 2-4 were purified using chromatography. It was found that the yields of dinaphthalocyanine complexes gradually decrease on going from europium to lutetium that agrees with the literature data. ${ }^{[14]}$ It was noted that the change of the yield correlates with the size of the central ion. Apparently, this is caused by a decrease in the lanthanide ionic radius from europium to lutetium and by the corresponding increase in the steric effect. Using of this approach allowed us to decrease the time of reaction and increase the yields of target complexes comparing to their analogues, which were obtained by the synthesis in solution. ${ }^{[13]}$ 
<smiles>N#Cc1cc2cc(Oc3ccccc3)c(Oc3ccccc3)cc2cc1C#N</smiles>

$\underset{\mathrm{Ln}(\mathrm{OAc})_{3} \cdot \mathrm{nH}_{2} \mathrm{O}}{\stackrel{2}{\longrightarrow}}$ 1) $220-310^{\circ} \mathrm{C}$ 2) $\mathrm{MW}, 700 \mathrm{~W}$

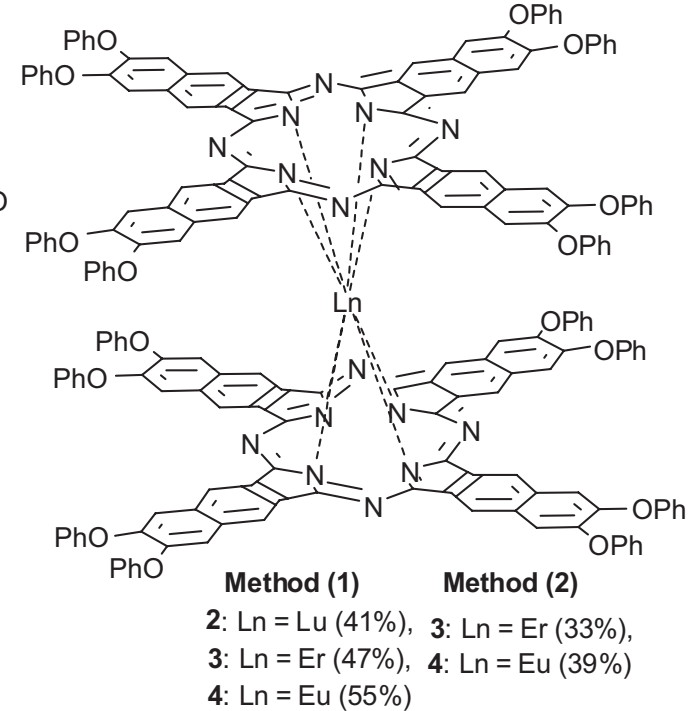

Scheme 1.

In addition to the melting method, the europium and erbium dinaphthalocyanine complexes were synthesized using microwave irradiation (MW). This method has been suggested for the first time for the synthesis of unsubstituted and octa-tert-butyl-substituted lanthanide diphthalocyanines ${ }^{[15]}$ and so far has not been used for preparation of naphthalocyanine complexes. Naphthalodinitrile $\mathbf{1}$ and acetates of the corresponding lanthanide salts were used to obtain the dinaphthalocyanine complexes. The synthesis was carried out by irradiation of a mixture of reagents in a microwave oven (Samsung, 1714R model). The power of irradiation was varied from 300 to 1000 $\mathrm{W}$, the time, from 3 to $10 \mathrm{~min}$. The following conditions were found to be optimal for the synthesis of dinaphthalocyanines with the use of the MW energy: the power of $700 \mathrm{~W}$ and the reaction time of 5-7 $\mathrm{min}$. The use of microwave irradiation of higher power led to destruction of 2,3-naphthalodinitrile 1. The use of MW allowed us to considerably simplify the synthesis (which can be carried out solvent-free), as well as to decrease the synthesis time from several hours to several

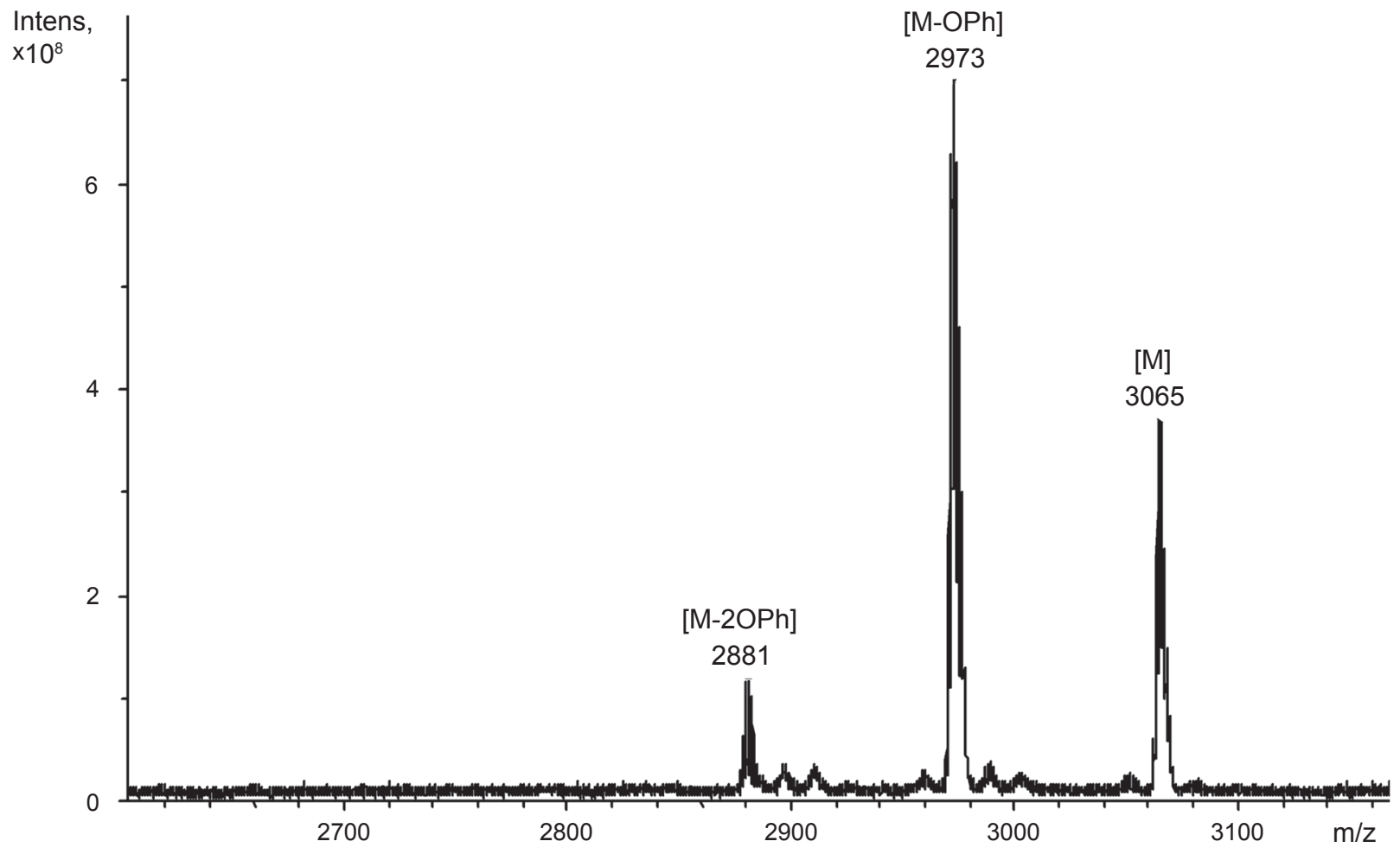

Figure 1. MALDI-TOF mass spectrum of $\mathbf{3}$. 
minutes. In the case of MW experiment, the main energy source is a MW irradiation, which more powerful, than the heating. Therefore, the reaction time decreased. The yields of dinaphthalocyanines are comparable with the results obtained by the melting method.

All complexes obtained were characterized using MALDI-TOF mass spectrometry, UV/Vis/NIR and ${ }^{1} \mathrm{H}$ NMR spectroscopy of reduced forms.

The MALDI-TOF mass spectra of these compounds (Figure 1, CHCA used as the matrix) revealed intense molecular ion $[M]^{+}$peak. It is also noteworthy that in the case of 3, two additional fragmentation peaks with molecular weight $[\mathrm{M}-\mathrm{OPh}]^{+*}$ and $[\mathrm{M}-2 \mathrm{OPh}]^{+\cdot}$ which were formed during laser ionization were observed.

\section{Spectral Properties}

Comparing to planar complexes some peculiarities were observed in the UV/Vis/NIR spectra of dinaphthalocyanines (Figure 2). There are three bands referring to singleoccupied molecular orbital (SOMO): ${ }^{[16]}$ blue valence (BV), red valence (RV) and intervalence (IV). IV band occupies wide region and possesses multiple peak nature, which is refered to equilibrium processes in sandwich molecule ${ }^{[17]}$ and corresponding splitting of energy levels. ${ }^{[18,19]}$ In contrast to diphthalocyanines ${ }^{[16]}$ of lanthanide the shape of this band doesn't exhibit dramatic changes for different central ions.

Noteworthy, that about $100 \mathrm{~nm}$ bathochromic shift of the $Q, \mathrm{BV}$ and IV bands was shown for dinaphthalocyanine complexes obtained in comparison with diphthalocyanines described in literature. ${ }^{[20]}$ The increasing of the ionic radius of lanthanide ion from $\mathrm{Lu}$ to Eu leads to the bathochromic shift of $Q, \mathrm{BV}$ and IV bands (Table 1). The stabilization of SOMO orbital results in the high values of shift for BV (transition HOMO-2 - SOMO) and IV (transition HOMO SOMO) bands. The IV-band of Eu complex 4 was the most red-shifted up to $1640 \mathrm{~nm}$.

At the same time the RV (transition SOMO - LUMO) exhibits a hypsochromic shift going from Lu to Eu (Table 1).

\section{Electrochemical Properties}

The redox properties of the dinaphthalocyanine complexes were investigated by cyclic voltammetry in a

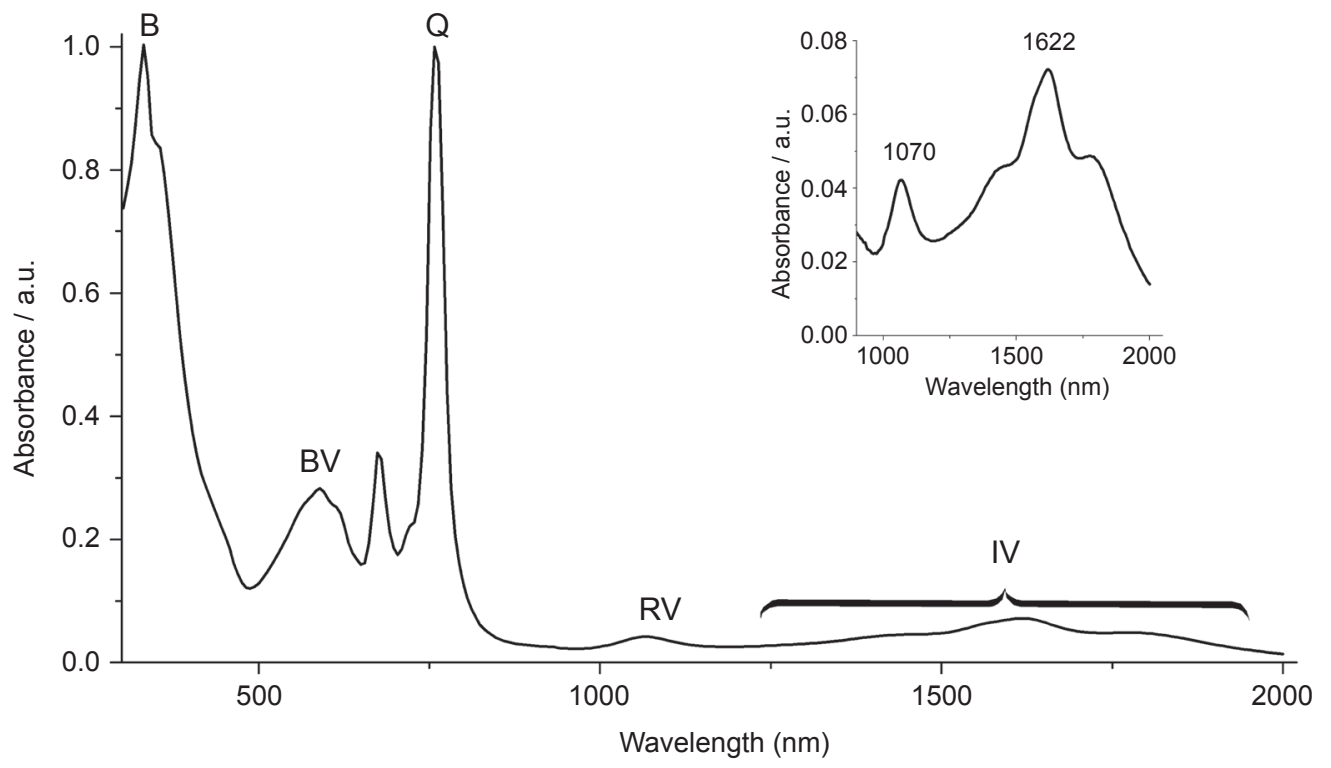

Figure 2. UV/Vis/NIR spectrum of 3 with magnified NIR region (inset) in $\mathrm{CCl}_{4}$.

Table 1. UV/Vis/NIR data and radii of central ion for dinaphthalocyanine complexes 2-4 in $\mathrm{CCl}_{4}$.

\begin{tabular}{ccc}
\hline Compound & $\lambda_{\max }, \mathrm{nm}\left(I / I_{\max }\right)$ & ionic radii, $\mathrm{pm}^{[21]}$ \\
\hline $\mathbf{2}$ & $337(1.00), 588(0.26), 675(0.30), 756(0.98), 1074(0.05), 1596(0.06)$ & 85 \\
$\mathbf{3}$ & $336(0.93), 590(0.24), 676(0.30), 760(1.00), 1068(0.04), 1616(0.06)$ & 89 \\
$\mathbf{4}$ & $332(1.00), 630(0.42), 681(0.44), 769(0.61), 1056(0.05), 1640(0.05)$ & 98 \\
\hline
\end{tabular}

Table 2. Half-wave potentials (V) for dinaphthalocyanine complexes 2-4 in $o$-DCB.

\begin{tabular}{ccccccc}
\hline Compound & $E_{1 / 2}\left(\mathrm{Ox}_{1}\right)$ & $E_{1 / 2}\left(\mathrm{Ox}_{2}\right)$ & $E_{1 / 2}\left(\operatorname{Red}_{1}\right)$ & $E_{1 / 2}\left(\operatorname{Red}_{2}\right)$ & $E_{1 / 2}\left(\operatorname{Red}_{3}\right)$ & $\Delta E\left(\operatorname{Red}_{1}-\operatorname{Red}_{2}\right)$ \\
\hline $\mathbf{2}$ & $0.34(-0.32)^{[\mathrm{a}]}$ & $1.33(0.67)$ & $-0.05(-0.71)$ & $-0.96(-1.62)$ & $-1.25(-1.91)$ & 0.91 \\
3 & $0.36(-0.30)$ & $1.32(0.66)$ & $0.00(-0.66)$ & $-0.96(-1.62)$ & $-1.25(-1.91)$ & 0.96 \\
$\mathbf{4}$ & $0.31(-0.35)$ & - & $0.05(-0.61)$ & $-0.98(-1.64)$ & $-1.34(-2.00)$ & 1.03 \\
\hline
\end{tabular}

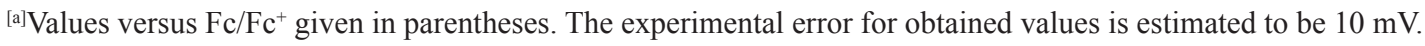




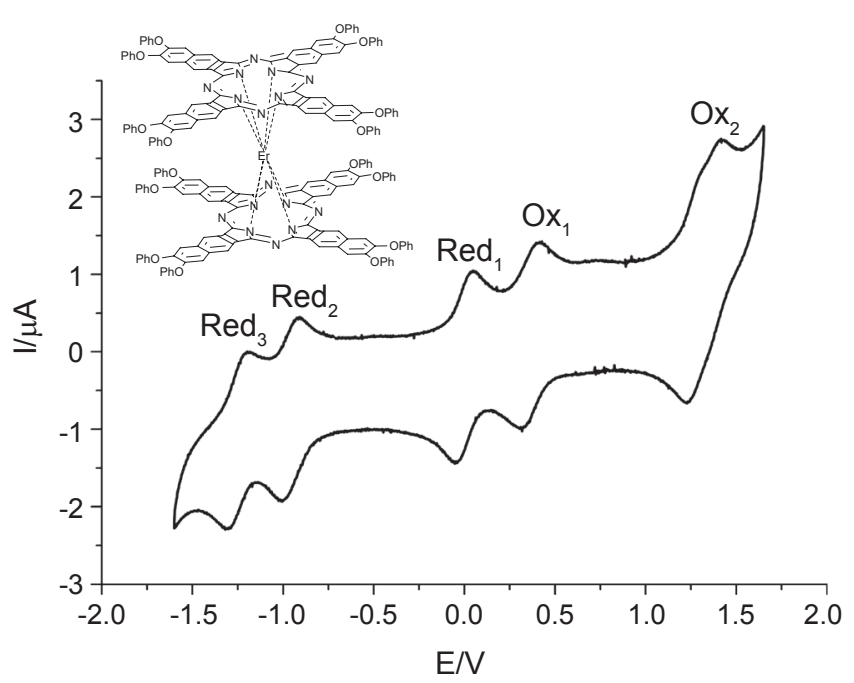

Figure 3. Cyclic voltammogram of $\mathbf{3}$ in $o$-DCB.

potential range of $-1.6-1.6 \mathrm{~V}$ and summarized in Table 2 . Erbium complex 3 demonstrated three reversible reductions and two reversible oxidations (Figure 3). Redox potential for $\mathrm{Ox}_{2}$ has not been determined in case of complex 4 , since the peaks for relatively diluted solutions of $\mathbf{4}$ were weak and $\mathrm{Ox}_{2}$ was probably located near the border or even out of the available window of potentials.

We observed a shift of $\operatorname{Red}_{1}$ to negative direction along with decreasing of ionic radii from $\mathrm{Eu}^{3+}$ to $\mathrm{Lu}^{3+}$. The similar shift of Red together with $\mathrm{Ox}_{1}$ is known for diphthalocyanines ${ }^{[22]}$ and explained by destabilization of SOMO with decreasing of distance between macrocycles. In case of the studied dinaphthalocyanines the shift of $\mathrm{Ox}_{1}$ was not obvious, probably because of an effect of peripheral substituents on interaction between macrocycles. The increase in $\Delta E\left(\operatorname{Red}_{1}-\operatorname{Red}_{2}\right)$ from $\mathrm{Lu}$ to $\mathrm{Eu}$ complexes is in accordance with the increase of HOMO-LUMO gap for single-electron reduced forms of diphthalocyanines, which was described in literature. ${ }^{[16]}$

\section{Conclusions}

Phenoxysubstituted sandwich-type naphthalocyanine complexes of lanthanides were synthesized in a melt under the heating and using microwave irradiation assisted approach. This approach was used to obtain dinaphthalocyanines for the first time. About $100 \mathrm{~nm}$ bathochromic shift of the $Q$, BV and IV bands was shown for dinaphthalocyanine complexes obtained in comparison with diphthalocyanines described earlier. IV-Band of Eu complex 4 was the most red-shifted up to $1640 \mathrm{~nm}$. The redox properties of the dinaphthalocyanine complexes were investigated by CVA. The presence of reversible redox processes was shown for all complexes obtained. The correlations between the radius of central ion of lanthanides and values of redox potentials were established.

Acknowledgements. The research was supported by the Russian Foundation for Basic Research (Grant No. 12-0300774) and the program of the Presidium of the Russian Academy of Science "Development of a strategy of organic synthesis and creation of compounds with valuable and applied proprieties".

\section{References}

1. Kobayashi N., Higashi Y., Osa T. Chem. Lett. 1994, 18131816.

2. Dubinina T.V., Ivanov A.V., Borisova N.E., Trashin S.A., Gurskiy S.I., Tomilova L.G., Zefirov N.S. Inorg. Chim. Acta 2010, 363, 1869-1878.

3. Makarov S.G., Suvorova O.N., Schnurpfeil G., Wöhrle D. Eur. J. Inorg. Chem. 2010, 2010, 4617-4621.

4. Kobayashi N., Nakajima S.-I., Ogata H., Fukuda T. Chem.-Eur. J. 2004, 10, 6294-6312.

5. Lukyanets E.A., Nemykin V.N. J. Porphyrins Phthalocyanines 2010, 14, 1-40.

6. Dubinina T.V., Trashin S.A., Borisova N.E., Boginskaya I.A., Tomilova L.G., Zefirov N.S. Dyes Pigm. 2012, 93, 14711480.

7. Dubinina T.V., Borisova N.E., Paramonova K.V., Tomilova L.G. Mendeleev Commun. 2011, 21, 165-167.

8. Trashin S.A., Dubinina T., Fionov A.V., Tomilova L. J. Porphyrins Phthalocyanines 2011, 15, 1195-1201.

9. Nyokong T. In: Functional Phthalocyanine Molecular Materials (Jiang J., Ed.), Berlin. 2010, p.45-88.

10. Dubinina T.V., Piskovoi R.A., Tolbin A.Y., Pushkarev V.E., Vagin M.Y., Tomilova L.G., Zefirov N.S. Russ. Chem. Bull., Int. Ed. 2008, 57, 1912-1918.

11. Pushkarev V.E., Breusova M.O., Shulishov E.V., Tomilov Y.V. Russ. Chem. Bull., Int. Ed. 2005, 54, 2087-2093.

12. Nemykin V.N., Kostromina N.A., Volkov S.V. Russ. Chem. Bull., Int. Ed. 1995, 44, 1883-1885.

13. Jiang J., Liu W., Poon K.-W., Du D., Arnold D.P., Ng D.K.P. Eur. J. Inorg. Chem. 2000, 2000, 205-209.

14. Pushkarev V.E., Ivanov A.V., Zhukov I.V., Shulishov E.V., Tomilov Y.V. Russ. Chem. Bull., Int. Ed. 2004, 53, 554-560.

15. Kogan E.G., Ivanov A.V., Tomilova L.G., Zefirov N.S. Mendeleev Commun. 2002, 12, 54-55.

16. Pushkarev V.E., Tolbin A.Y., Zhurkin F.E., Borisova N.E., Trashin S.A., Tomilova L.G., Zefirov N.S. Chem.-Eur. J. 2012, 18, 9046-9055.

17. Gasyna Z., Schatz P.N., Boyle M.E. J. Phys. Chem. 1995, 99, 10159-10165.

18. Rousseau R., Aroca R., Rodríguez-Méndez M.L. J. Mol. Struct. 1995, 356, 49-62.

19. Dunford C.L., Williamson B.E., Krausz E. J. Phys. Chem. A 2000, 104, 3537-3543.

20. Nalwa H.S. Supramolecular Photosensitive and Electroactive Materials. Academic Press, 2001.

21. Emsley J. Elements (russ. transl.). Moscow: Mir, 1993.

22. Zhukov I.V., Pushkarev V.E., Tomilova L.G., Zefirov N.S. Russ. Chem. Bull., Int. Ed. 2005, 54, 189-194. 